\title{
White Elite Women, the Gendered Memory of Heroism, and American Nationalism, 1890-1939
}

\section{Simon Wendt}

It is well known that heroes serve crucial functions in human societies. They embody the norms, values, and beliefs of social groups; they are crucial to the formation of collective identities; and they frequently become role models that people seek to emulate. As symbols of hegemonic norms and identities, heroic men and women constitute central sources of authority and are used to legitimize social, cultural, and racial hierarchies. Yet, although heroism tends to be a stabilizing force in society, it is constantly debated, reevaluated, and revised. As people's norms and values change over time, so do heroes' attributes and the functions they serve. ${ }^{1}$

Despite the thousands of pages that have been devoted to heroism in the United States, including military heroes, heroic leaders, and super heroes, few scholars have focused on those whose admiration and praise ultimately create heroes. ${ }^{2}$ This article seeks to bridge this historiographical gap by examining the Daughters of the American Revolution, a non-governmental group of "hero mak-

1 O. E. Klapp, The Creation of Popular Heroes, in: American Journal of Sociology 54, Issue 2, 1948, pp. 135-141; J. Hume, Changing Characteristics of Heroic Women in Midcentury Mainstream Media, in: Journal of Popular Culture 34, Issue 1, 2000, pp. 9-29, here p. 9; T. Potter Coffin / H. Cohen (eds.), The Parade of Heroes: Legendary Figures in American Lore, Garden City, NY 1978, p. xxiii; L. Strate, Heroes: A Communication Perspective, in: S. J. Drucker / R. S. Cathcart (eds.), American Heroes in a Media Age, Cresskill, NJ 1994, pp. 15-23, here p. 15; L. Strate, Heroes and/as Communication, in: S. J. Drucker / G. Gumpert (ed.), Heroes in a Global World, Cresskill, NJ 2008, pp. 19-44, here p. 19; W. J. Goode, The Celebration of Heroes: Prestige as a Control System, Berkeley 1978, pp. 7-8, pp. 151-152.

2 For examples of this historiography, see O. E. Klapp, Heroes, Villains, and Fools: The Changing American Character, Englewood Cliffs 1962; H. Lubin (ed.), Heroes and AntiHeroes: A Reader in Depth, San Francisco 1968; M. Fishwick, The Hero, American Style: Changing Ideas of Greatness from John Smith to John Kennedy, New York 1969; M. Gerzon, A Choice of Heroes: The Changing Faces of American Manhood, Boston 1982; E. T. Linenthal, Changing Images of the Warrior Hero in America: A History of Popular Symbolism, New York 1982; B. Schwartz, George Washington and the Whig Conception of Heroic Leadership, in: American Sociological Review 48, Issue 1, February 1983, pp. 18-33; B. Schwartz, Abraham Lincoln in the Post-Heroic Era: History and Memory in Late Twentieth-Century America, Chicago 2008; A. J. Huebner, The Warrior Image: Soldiers in American Culture from the Second World War to the Vietnam Era, Chapel Hill, NC 2008; L. Tye, Superman: The High-Flying History of America's Most Enduring Hero, New York 2012; J. Dittmer, Captain America and the Nationalist Superhero: Metaphors, Narratives, and Geopolitics, Philadelphia 2013. 
ers" in the United States who looked to the past to find what they believed were heroic male and female patriots. Covering the period 1890 to 1939, the article focuses on the question of how the DAR used the gendered memory of heroism to strengthen American patriotism. For the purposes of this essay, gendered memory of heroism is defined as a dynamic process through which historical figures are "heroized" to strengthen certain notions of femininity and masculinity in the present. Answering the question of how this group of hero-makers utilized this form of memory will help us better understand one particular audience that was responsible for the perpetuation of mythical stories about the American past and sought to deliberately employ them to boost citizens' patriotism in the late nineteenth and early twentieth centuries. Just as importantly, it will shed light on the ways in which white elite women contributed to US nationalism and on what role gender played in the commemoration of the pantheon of the American heroes and heroines of the past around 1900. Ultimately, the DAR must be regarded as an "active" audience that was not satisfied to merely "consume" traditional heroic fare, which traditionally catered to a male audience, but rather actively challenged these traditions, even though their challenge did little to alter existing gender hierarchies. This essay therefore speaks not only to the ambiguities of the impact of the heroic imagination and re-imagination on notions of gender and gender hierarchies in the United States prior to World War II; it also helps us better understand the problems that historians face when trying to disentangle the similarities and differences between "hero makers" and the audiences that the hero-making process is intended to reach.

\section{Heroism and Hero-Worship in Nineteenth-Century America}

Before the Daughters of the American Revolution and their commemorative campaigns are analyzed in greater detail, it is pertinent to briefly discuss the history of heroism before and after the organization's founding. Well into the twentieth century, two particular hero types dominated the heroism discourse in Europe and North America: the warrior hero and the heroic military or political leader. In Western cultures, the warrior hero first emerged in ancient Greek mythology, which told of courageous fighters who ventured into the unknown, risked their lives during extraordinary feats, and triumphantly returned home to be praised, honored, and commemorated. In many cultures, such heroic warriors were depicted as half-divine men with superhuman strength, whose deeds were glorified in oral traditions as well as in written form. During the middle ages, battle-hardened knights received similar praise for their chivalric valor. Heroic military and political leaders were just as revered because they, in the words of eminent historian Sidney Hook, assumed the aura of "event-making" men who changed the course of history because of their extraordinary intelligence, will, and character. From the perspective of nineteenth-century scholars such as Thomas Carlyle, the history of the 
world was but "the Biography of Great Men." American dictionaries that were published between 1800 and 1900 tended to reflect the cultural hegemony of these two hero types, since most of them defined heroes either as "brave warriors" or as "great persons."3

But it was also during the nineteenth century that these two hero types underwent significant changes. In an intertwined process whose earliest manifestations could be observed in the United States, heroism was simultaneously nationalized and democratized. As new nation-states emerged in Europe and North America, warrior heroes and heroic leaders became revered symbols of nationhood. After the American Revolution, for instance, heroic general and first US President George Washington became an almost mythical figure who was said to embody the new Republic. Martyred president Abraham Lincoln was elevated to similarly powerful symbolic stature after the American Civil War. More importantly, official recognition of fighters' valor on the battlefield, which had long been confined to the upper echelons of the military hierarchy, was increasingly extended to ordinary servicemen for their willingness to die for the nation. A number of rank-and-file soldiers were commended for successfully defending the young republic during the War of 1812 and the Mexican War (1846-1848), although few military decorations existed to match that sentiment, because many commentators believed that medals for war heroes smacked of European aristocracy. The Civil War (1861-1865) and the Spanish-American War (1898) eventually transformed ordinary warrior heroes into icons of US nationalism, which was symbolized by the introduction of the Medal of Honor in 1862, an award that was given for "conspicuous gallantry and intrepidity at the risk of life above and beyond the call of duty" and which became an emblem of patriotic and courageous service on the battlefield during the Spanish-American War. ${ }^{4}$ The soldiers who received such awards continued to be admired as daring risk takers who embodied manly honor, but their recognition as heroes was now inextricably linked to the willingness to

3 B. Giesen, Triumph and Trauma (The Yale Cultural Sociology Series), Boulder, CO/ London 2004, p. 15; K. Kerényi, Die Heroen der Griechen, Zürich 1958, pp. 12-24; J. Campbell, The Hero with a Thousand Faces, London 1993, pp. 30-37; S. Hook, The Eventful Man and the Event-Making Man, in: H. Lubin (ed.), Heroes and Anti-Heroes: A Reader in Depth, San Francisco 1968, pp. 132-138; T. Carlyle, On Heroes, Hero-Worship, and the Heroic in History, London 1841 (Repr. Leipzig 1916), p. 21; Hume, Changing Characteristics of Heroic Women (footnote 1), p. 9.

4 K. Hagemann, Of 'Manly Valor' and 'German Honor': Nation, War, and Masculinity in the Age of the Prussian Uprising Against Napoleon, in: Central European History 30, Issue 2, 1997, pp. 187-220, here p. 219; R. Schilling, „Kriegshelden“: Deutungsmuster heroischer Männlichkeit in Deutschland, 1813-1945, Paderborn 2002, p. 26; Schwartz, George Washington and the Whig Conception of Heroic Leadership (footnote 2), pp. 2024; B. Schwartz, George Washington: The Making of an American Symbol, New York 1987; J. Pettegrew, 'The Soldier's Faith': Turn-of-the-Century Memory of the Civil War and the Emergence of Modern American Nationalism, in: Journal of Contemporary History 31, Issue 1, January 1996, pp. 49-73; Awards, Decorations, and Honors, in: B. H. Norton (ed.), Encylcopedia of American War Heroes, New York 2002, pp. xvii-xxvii. 
sacrifice their lives for the nation. The hundreds of monuments that were built to commemorate southern and northern Civil War soldiers between 1870 and 1910 as well as countless nineteenth-century school textbooks that used heroic tales of American fighters to inculcate national loyalty hammered home the message that men's heroic death on the battlefield constituted the highest form of patriotism. ${ }^{5}$

Despite the growing inclusivity of heroism, however, it was a form of acclaim that remained largely confined to white men, a limitation that is important to note in the context of US history. The white warrior hero remained the most cherished paragon of masculinity, epitomizing valor, physical strength, and honor. Women, by contrast, were rarely depicted as active agents in heroic tales. National heroines in particular were conspicuously absent from the print media's stories of courage and daring. If heroic women appeared at all, their exploits were frequently used allegorically as part of a male-centered nationalist discourse or denoted particularly feminine virtues that reinforced dichotomous notions of gender. Just as warrior heroes became exemplars of masculinity, the few heroic women that appeared in published stories were upheld as perfect examples of Victorian femininity. ${ }^{6}$

African Americans were similarly absent from such popular tales of heroism. Although men of color repeatedly proved their valor on the battlefield, they were generally regarded as effeminate cowards by nature. Neither the almost 200,000 black soldiers who fought bravely for the Union during the Civil War nor the African American men who saw action during the Spanish-American War received more than token appreciation for their military service. In the case of the conflict with Spain, Colonel Theodore Roosevelt even openly disparaged the black members of his legendary Rough Riders for their supposed lack of bravery on Cuban battlefields. African American pundits and journalists tried hard to dispel the myth of black cowardice. Famous scholar and civil rights activist W. E. B. Du Bois unearthed heroic deeds of African Americans in the past and praised their manly exploits in the present, while black editors similarly called attention to the daring deeds of soldiers of color. Despite these efforts to counter the accusations of Theodore Roosevelt and others, however, white Anglo-Saxon heroism reigned supreme in the late nineteenth and early twentieth

5 Goode, The Celebration of Heroes (footnote 1), pp. 167-179; U. Frevert, Vom heroischen Menschen zum „Helden des Alltags“, in: Merkur 63, Issue 9/10, September/October 2009, pp. 803-812; Id., Männer und Heroen: Vom Aufstieg und Niedergang des Heroismus im 19. und 20. Jahrhundert, in: R. van Dülmen (ed.), Erfindung des Menschen: Schöpfungsträume und Körperbilder, 1500-2000, Vienna 1998, pp. 323-346; M. Kammen, Mystic Chords of Memory: The Transformation of Tradition in American Culture, New York 1991, p. 115; Linenthal, Changing Images of the Warrior Hero in America (footnote 2), p. 27.

6 R. W. Connell, Masculinities, Cambridge 1995, pp. 37-38, p. 78, p. 213; K. A. Boon, Heroes, Metanarratives, and the Paradox of Masculinity in Contemporary Western Culture, in: Journal of Men's Studies 13, Issue 3, 2005, pp. 301-312, here pp. 303-304; J. S. Goldstein, War and Gender: How Gender Shapes the War System and Vice Versa, Cambridge 2001, pp. 265-272, pp. 274-279; Hume, Changing Characteristics of Heroic Women (footnote 1), pp. 9-10. 
century, reinforcing the conclusions of pseudo-scientific research on the alleged inferiority of non-white people and racial hierarchies that had become a way of life in the southern United States, although racial segregation was commonplace in the rest of the country as well. ${ }^{7}$ The Daughters of the American Revolution sought to challenge some of these traditions of hero-worship while simultaneously contributing to the perpetuation of others.

\section{The Daughters of the American Revolution and the Gendered Memory of Heroism, 1890-1939}

The DAR was founded in 1890 in Washington, DC, in response to the refusal of the Sons of the American Revolution to admit women, reflecting a political dimension of its work that echoed ideas that were voiced by many women's clubs at the time. Its members were and are still required to prove lineal descent from American patriots who actively contributed to the cause of American independence. This relative exclusivity, coupled with a growing interest in genealogy and patriotic memory around 1900, made the Daughters extremely popular and helped them spread their nationalist message. By the mid-1920s, the organization boasted a membership of almost 200,000. Throughout its history, the organization's membership has consisted primarily of white middle-class Protestants, many of whom were and are college-educated. Although many of their activities revolved around commemoration, the Daughters also took an avid interest in current affairs. This became especially apparent after World War I, when the DAR became the vanguard of a powerful movement of private groups that sought to detect and stop "radical" and communist subversion. Prior to the Great War, the Daughters had been involved in the Progressive Movement, but during the 1920s, they abandoned much of their liberal agenda and became vocal advocates of military preparedness, restrictive immigration legislation, and anticommunism. The DAR's campaigns against what it considered "un-American" radicalism included many other "isms," among them pacifism as well as feminism. In fact, the organization only grudgingly accepted woman suffrage after the passage of the Nineteenth Amendment in 1919 and was convinced that feminists were unknowing dupes of Communist radicals who wanted to destroy America. Their penchant for such conspiracy theories made them the target of a lot of ridicule in the 1920s and early 1930s. But the absolute low point of the organization's reputation came

7 W. L. Van Deburg, Black Camelot: African-American Culture Heroes in Their Times, 1960-1980, Chicago 1997, pp. 24-37; N. I. Huggins, W. E. B. Du Bois and Heroes, in: Amerikastudien 34, Issue 2, 1989, pp. 167-174; Pettegrew, 'The Soldier's Faith' (footnote 4), pp. 64-68; S. Wendt, Krieg und Heldentum in den USA: Die Heroisierung amerikanischer Soldaten vom Ende des Bürgerkriegs bis zum spanisch-amerikanischen Krieg, in: C. Arendes / J. Peltzer (ed.), Krieg. Vergleichende Perspektiven aus Kunst, Musik und Geschichte, Heidelberg 2007, pp. 115-132; C. Bold, Where Did the Black Rough Riders Go?, in: Canadian Review of American Studies 39, Issue 3, 2009, pp. 273-297, here p. 274. 
in 1939, when the DAR barred famous black opera singer Marian Anderson from its Constitution Hall in Washington, DC. Its discriminatory actions became an unexpected opportunity for civil rights activists to call attention to the reality of racial segregation in the capital and the rest of the country. With the help of the administration of Franklin D. Roosevelt, these activists organized a protest concert that took place on Easter Sunday 1939 on the steps of the Lincoln Memorial in Washington, DC. There, Marian Anderson thrilled an audience of almost 75,000 . Today, the Daughters are remembered primarily for this widely publicized incident, and their reputation has suffered accordingly. ${ }^{8}$

But prior to 1939, the Daughters of the American Revolution were an influential player in the efforts of non-governmental groups to strengthen American nationalism, and the organization's gendered memory of heroism played a significant role in these efforts. The DAR constituted a conservative white middle-class audience that readily consumed heroic tales it deemed crucial to strengthening the patriotism of the American populace. At the same time, its members refused to remain passive consumers, taking on the role of active "hero makers" who used their commemorative campaigns to tell Americans not only how to be more patriotic citizens, but also how to be "true" women and "real" men, suggesting that these two aspects of what it meant to be an American citizen were inextricably intertwined.

Studying this complex interrelationship requires a theoretical foundation that helps us to disentangle the interconnections of nationalism, gender, and memory. First, the interrelationship between nationalism and gender needs to be discussed. In this essay, nationalism is defined as an ideology that revolves around three main beliefs: that a sovereign nation exists; that its members have a common history and a common territory; and that loyalty to the nation trumps all other loyalties. ${ }^{9}$ But nationalism is also a relational ideology, which means that it is always intertwined with other identity concepts, among them race and gender, which can be defined as the process through which dichotomous views of masculinity and femininity are performatively produced, practiced, and naturalized as

8 On this history, see W. E. Davis, Patriotism on Parade: The Story of Veterans' and Hereditary Organizations in America, 1783-1900, Cambridge 1955; F. C. Morgan, 'Home and Country': Women, Nation, and the Daughters of the American Revolution, 1890-1939, Ph.D. diss., Columbia University 1998; K. E. Nielsen, Un-American Womanhood: Antiradicalism, Antifeminism, and the First Red Scare, Columbus, OH 2001; F. C. Morgan, Women and Patriotism in Jim Crow America, Chapel Hill, NC 2005; R. Arsenault, The Sound of Freedom: Marian Anderson, The Lincoln Memorial, and the Concert that Awakened America, New York 2009; S. A. Sandage, A Marble House Divided: The Lincoln Memorial, the Civil Rights Movement, and the Politics of Memory, 1939-1963, in: Journal of American History 80, Issue 1, June 1993, pp. 135-167; A. Black, Championing a Champion: Eleanor Roosevelt and the Marian Anderson 'Freedom Concert,' in: Presidential Studies Quarterly 20, Issue 4, 1990, pp. 719-736.

9 J. Breuilly, Nationalism and the State, Chicago ${ }^{2} 1994$, p. 2; C. Calhoun, Nationalism, Buckingham 1997, pp. 4-5; N. Yuval-Davis, Gender \& Nation, Thousand Oaks, CA 1997, p. 21. 
stable and fixed. ${ }^{10}$ Nationalism and gender are interrelated because they continually produce each other. Nationalism actively constructs and is dependent on gender difference, while the idea of fixed gender identities contributes to the belief that the nation, too, is natural and unchanging. In American nationalist discourse around 1900, this interrelationship can be seen in three recurring themes: heroism, motherhood, and the family. In the case of men, only their willingness to die a hero's death on the battlefield was seen as unequivocal evidence of both their manly identity and their loyalty to the fatherland. Mothers, on the other hand, were regarded as biological and cultural reproducers of the nation, which some deemed heroic, including the Daughters of the American Revolution. To most men, however, bearing and rearing children was a service to the nation that was expected of women as members of the nation; yet, women were also expected to remain pure, chaste, and modest to be accepted as "true" members of that "imagined community." The ideal of the patriarchal family not only strengthened such notions of masculinity and femininity, but also simultaneously bolstered American nationalism, since the family was seen as the smallest unit of the nation. Men's dominance over women and children in the family household was depicted as a natural hierarchy that symbolized social and political hierarchies within the nation. Nationalism thus consolidated gender dichotomies and ultimately depended on the continuous enforcement of these dichotomies. ${ }^{11}$

Memory is an essential element in the process through which nationalism and gender produce each other. For the purposes of this essay, memory is defined broadly as selective interpretations of the past that shape collective norms and identities in the present. Of course, memory is constantly debated and reinterpreted, since it is part and parcel of struggles over social, cultural, and political power. Just as importantly, there are always multiple and often contradictory

10 See J. W. Scott, Gender: A Useful Category of Historical Analysis, in: American Historical Review 91, Issue 5, December 1986, pp. 1053-1075; J. W. Scott, Unanswered Questions, in: American Historical Review 113, Issue 5, December 2008, pp. 1422-1429; J. Meyerowitz, A History of 'Gender', in: American Historical Review 113, Issue 5, 2008, pp. 13461356; J. Butler, Gender Trouble: Feminism and the Subversion of Identity, New York 1990.

11 Yuval-Davis, Gender \& Nation (footnote 9), pp. 22-24; J. Nagel, Masculinity and Nationalism: Gender and Sexuality in the Making of Nations, in: Ethnic and Racial Studies 21, Issue 2, March 1998, pp. 242-269; D. Kondo, Fabricating Masculinity: Gender, Race, and Nation in a Transnational Frame, in: C. Kaplan [et al.] (ed.), Between Woman and Nation: Nationalisms, Transnational Feminisms, and the State, Durham 1999, pp. 296-319; A. McClintock, Family Feuds: Gender, Nationalism and the Family, in: Feminist Review 44, 1993, pp. 61-80; A. McClintock, 'No Longer in a Future Heaven': Gender, Race, and Nationalism, in: A. McClintock [et al.] (ed.), Dangerous Liaisons: Gender, Nation, and Postcolonial Perspectives, Minneapolis, MN 1997, pp. 89-112. See also A. Parker [et al.] (ed.), Nationalisms and Sexuality, New York 1992; I. Blom [et al.] (ed.), Gendered Nations: Nationalisms and Gender Order in the Long Nineteenth Century, Oxford 2000; Y. AbuLaban (ed.), Gendering the Nation-State: Canadian and Comparative Perspectives, Vancouver 2008 . 
memories, which makes analyzing them very difficult. ${ }^{12}$ To disentangle these various memories and to understand how they are interconnected, Egyptologist Jan Assmann's conceptual differentiation between "communicative memory" and "cultural memory" is very useful. Communicative memory stands for "living memory," which is passed on orally within families or towns as part of everyday life. Since it is living memory, it reaches back only $80-100$ years and vanishes with the death of the last person who remembers the past. Cultural memory, by contrast, is a formalized and lasting form of collective memory, which is deliberately preserved by elite groups such as politicians or the Daughters of the American Revolution to strengthen collective identities in the present. These two forms of remembrance are intertwined because the memories of families, towns, regions, and the nation are frequently connected with and ultimately fused into the collective memory of one single "imagined community." 13 These conceptual distinctions are of importance for scholars of heroism because the memory of heroes and heroines affects and is affected by various communities of interpretationthat is audiences-that can be passive consumers or active agents in hero-making processes. At the same time, there is considerable overlap between these audiences, and people frequently partake in several of these communities simultaneously.

The commemorative campaigns of the Daughters of the American Revolution reveal much about these complexities as well as the question of how the organization used the gendered memory of heroism to strengthen American patriotism. In the following pages, three aspects of the DAR's tributes to the past will be discussed in greater detail: the memory of women during the American Revolution; the memory of Western expansion; and the memory of Native Americans.

With regard to the American Revolution the Daughters sought to counter traditional interpretations of the defining moment of US history because they were rankled by the traditional focus on the heroic accomplishments of men in public discourse. They regarded the women of the Revolution as patriotic heroines whose contributions to American independence had been just as important as those of men. Yet the Daughters' adulations were ambiguous because they praised Revolutionary women's patriotism within the confines of nineteenthcentury gender ideals. They paid tribute to two types of female patriots. The first type of patriotic heroine was the wife and mother who managed the household

12 E. Zerubavel, From Social Memories: Steps towards a Sociology of the Past, in: J. K. Olick [et al.] (ed.), The Collective Memory Reader, Oxford 2011, pp. 221-224, here p. 223; D. Lowenthal, The Past is a Foreign Country, Cambridge 1985, p. 210; B. Schwartz, Abraham Lincoln and the Forge of National Memory, Chicago 2000, p. 18; W. F. Brundage, Introduction: No Deed but Memory, in: W. F. Brundage (ed.), Where These Memories Grow: History, Memory, and Southern Identity, Chapel Hill, NC 2000, pp. 1-22.

13 J. Assmann, Collective Memory and Cultural Identity, in: New German Critique 65, 1995 , pp. 125-133. See also J. Assmann, Cultural Memory and Early Civilization: Writing, Remembrance, and Political Imagination, Cambridge 2011. 
and raised her children while husbands and sons were fighting for American independence. The wife and mother was also deemed heroic because she had ministered to wounded soldiers or helped feed members of the Continental Army. ${ }^{14}$ The Daughters thus constructed a sex-specific form of heroism that is revealed in an article that was published in the DAR's monthly magazine in 1897. In that article, a DAR member wrote:

"in the great struggle [...] for freedom, woman proved herself man's helpmate, as God intended her to be. Not hers to bear the musket, wield the sword, or charge with bayonet upon the field of battle, but a true patriot, wife and mother was woman, who [...] has performed astonishing deeds of heroism." 15

This quote shows that the Daughters wanted men to acknowledge women's heroic contributions to the Revolution; at the same time, they argued that the women of the past, like their descendants in the present, gladly served as mere supporters who would not challenge men's supremacy as nation-builders.

In the case of the second type of female heroism, the Daughters put even more emphasis on women's agency as historical actors, since they honored those women who had actually taken up arms to defend the American nation. But even these women were regarded primarily as patriotic supporters of their husbands. ${ }^{16}$ One such heroine was Margaret Corbin, who in 1776 helped her husband James load his cannon during the battle of Fort Washington and later served the gun after James was killed by British bullets. Shortly after replacing her husband, Corbin herself was wounded by enemy fire and was taken to a field hospital. Although Corbin subsequently received a veteran's pension and became part of regional lore, it was not until Daughters from New York researched her life that she received official recognition for her exploits. As early as 1902, a DAR Chapter placed a bronze tablet on the wall of a church near the battlefield to commemorate her bravery. And in 1926, after years of researching the location of Corbin's grave, the New York State DAR obtained official permission to

14 J. E. Richards, Heroic Women of the American Revolution, in: American Monthly Magazine, September 1892, p. 278; Daughters of the Revolution, in: New York Times, February 23, 1896, p. 12; Daughters of Patriots, in: Boston Daily Globe, September 26, 1895, p. 3; Mrs. B. A. Fassenden, Woman, Teacher of Patriotism, in: American Monthly Magazine, July 1905, pp. 8-13; Daughters of the Revolution, in: Washington Post, February 15, 1898, p. 6; All the Woman's Club News of Georgia, in: Atlanta Constitution, July 16, 1905, p. D6; E. C. Barney Buel, A Mother of the American Revolution, in: DAR Magazine, September 1924, p. 361; Mrs. M. E. Seymour, Revolutionary Heroines, in: DAR Magazine, September 1936, pp. 933-934.

15 The Women of the Revolution, in: American Monthly Magazine, October 1897, p. 356.

16 A Woman Patriot, in: American Monthly Magazine, February 1893, pp. 225-226; A New Jersey Heroine, in: DAR Magazine, December 1914, p. 339; Richards, Heroic Women of the American Revolution (footnote 14), pp. 286-287; C. B. Bird, Women of Revolutionary Times in New England, in: American Monthly Magazine, June 1913, p. 306; G. M. Pierce, Three American Women Pensioned for Military Service, in: DAR Magazine, September 1917, pp. 140-145; Mrs. J. Gates Jr., Contributions of Women to the American Revolution, in: DAR Magazine, September 1931, pp. 544-545. 
remove her body from her grave and to have the remains reinterred in the US Military Cemetery at West Point. There the Daughters erected a granite monument which bore a bronze tablet that recounted her heroic deed. Yet, although the Daughters praised Corbin's heroism, they stressed that it had been a combination of her loyalty toward her husband and the nation that made her assume a soldier's duty. From the DAR's perspective, Corbin had abandoned neither the tenets of true womanhood nor the duties of Republican motherhood. ${ }^{17}$ In the case of the Revolution, then, the DAR's remembrance stressed women's agency in history but also served to perpetuate traditional gender hierarchies, which the Daughters deemed vital to the stability of the nation.

The DAR's memory of Western pioneers reveals dynamics that are similar to the ones that became apparent in the organization's interpretation of the American Revolution. From the perspective of the Daughters, Western pioneer settlers were almost as important as the heroic patriots of the American Revolution. The reason for this particular interest was the fact that Midwestern and Western Daughters could not create any commemorative links between the Revolution and their local communities. They lacked revolutionary battlefields and buildings from the colonial period, which is why they focused on the remembrance of Western expansion..$^{18}$ Many of the historical narratives they constructed revolved around ordinary Pioneer families from the Northeast, who during the 1840s and 1850s undertook arduous journeys to begin a new life in the Far West. During this period, thousands of such families moved west, and they followed a number of trails, most of which started in Missouri. In the case of the Oregon Trail, their journey ended in Olympia, Washington State. Those who followed the Santa Fe Trail could travel as far as Santa Fe, New Mexico. ${ }^{19}$

17 R. P. Bolton, Margaret Corbin, in: New York Times, April 27, 1902, p. SM4; Tablets Marking Historic Sites and Other Memorials, in: American Monthly Magazine, January 1909, pp. 12-18; To Rebury Captain Mollie, in: New York Times, January 28, 1926, p. 9; Honors Molly Corbin by two Ceremonies, in: New York Times, April 15, 1926, p. 27; A. C. Parker, Revolutionary Heroine Interred in West Point Cemetery, in: DAR Magazine, June 1926, pp. 347-352; Bird, Women of Revolutionary Times in New England (footnote 16), p. 306. For studies on Republican Motherhood, see, for example, M. A. Nash, Rethinking Republican Motherhood: Benjamin Rush and the Young Ladies' Academy of Philadelphia, in: Journal of the Early Republic 17, Issue 2, Summer 1997, pp. 171-191; M. B. Norton, Liberty's Daughters: The Revolutionary Experience of American Women, 1750-1800, Ithaca 1980.

18 Morgan, 'Home and Country' (footnote 8), pp. 56-58, pp. 167-170; F. C. Morgan, 'Regions Remote from Revolutionary Scenes': Regionalism, Nationalism, and the Iowa Daughters of the American Revolution, 1890-1930, in: Annals of Iowa 56, Issue 1/2, 1997, pp. $50-54$, p. 58 , p. 60 , p. 76, p. 78.

19 On the history of these two trails, see W. Bagley, So Rugged and Mountainous: Blazing the Trails to Oregon and California, 1812-1848, Oklahoma 2010; F. McLynn, Wagons West: The Epic Story of America's Overland Trails, London 2002; D. Dary, The Santa Fe Trail: Its History, Legends, and Lore, Lawrence 2000; S. G. Hyslop, Bound for Santa Fe: The Road to New Mexico and the American Conquest, 1806-1848, Norman 2002; D. Lavender, Westward Vision: The Story of the Oregon Trail, Lincoln ${ }^{2} 1985$. 
Interestingly, prior to World War I, and in contrast to the memory of the American Revolution, Western Daughters stressed the accomplishments of Pioneer heroes, not the exploits of heroic women. In large part, the Daughters admired these men because they regarded them as masculine warrior heroes, who had bravely resisted Native American attacks and frequently lost their lives in these conflicts. Their death was seen as a manly sacrifice for Western civilization and the American nation. This demonstrates that the DAR's gendered nationalism frequently intersected with race. To honor these heroic men, the Daughters erected hundreds of monuments along the trails on which the pioneers had traveled. Most of them were rather unremarkable granite boulders or concrete shafts. ${ }^{20}$ What made these monuments remarkable was the unique dialogue between communicative and cultural memory that led to their construction. The Daughters repeatedly tapped the living communicative memory that lingered in local communities to create the heroic cultural memory that they believed would strengthen the patriotism of US citizens. For example, they interviewed old pioneers who had undertaken the journey prior to the Civil War and used their reminiscences to reconstruct the routes of the trails, which had been largely forgotten by the late nineteenth century. More importantly, during the dedication ceremonies that were organized for each monument, this communicative memory was integrated into nationalist rituals that were witnessed by hundreds, sometimes thousands of local citizens. In patriotic speeches, pioneers, politicians, and DAR officers reminded their audiences that they needed to emulate the heroic example of their ancestors. ${ }^{21}$ During such dedication ceremonies, nationalism became meaningful to those who attended them because the history of their families was presented as a crucial building block in the history of the nation. Family history and national history appeared to become one.

20 Mrs. W. E. Stanley, Marking the Santa Fe Trail Through Kansas, in: American Monthly Magazine, February 1907, p. 139; Mrs. C. O. Norton, The Old Oregon Trail, in: American Monthly Magazine, March 1909, pp. 255-257; The Old Oregon Trail, in: American Monthly Magazine, August 1910, p. 89; H. C. Van Brunt, Report of the Santa Fe Trail Committee, January 13, 1913, in: Van Brunt Papers, Folder 13; Western Historical Manuscript Collection-Columbia, Columbia, MO; H. C. Van Brunt, Report of Santa Fe Trail Committee, October 14, 1908, in: Van Brunt Papers, Folder 12; D.A.R. Saw Danger of Forgotten Trail and Marked Famous Route, in: Kansas City Journal Post, September 6, 1925, p. 6-F; Mrs. C. O. Norton, The Old Oregon Trail, in: American Monthly Magazine, November 1911, pp. 254-259; Report of Old Oregon Trail Committee, April 1, 1914. Daughters of the American Revolution: Minutes of the Oregon Trail Committee, D.A.R. State of Washington Collection, Seattle Public Library, Seattle, WA; M. Lindly (ed.), Nebraska State History of the Daughters of the American Revolution, Lincoln 1929, p. 346.

21 Norton, The Old Oregon Trail (footnote 20); Lindly, Nebraska State History of the Daughters of the American Revolution (footnote 20), p. 346; G. H. Himes to Mrs. J. W. Ellis, January 7, 1915, Daughters of the American Revolution (footnote 20), Minutes of the Oregon Trail Committee, D.A.R. State of Washington Collection; The Santa Fe Trail, in: American Monthly Magazine, January 1908, pp. 14-15; H. C. Van Brunt, Madam State Regent and Other Members of the Ninth State Conference, October 1908, Folder 12, Western Historical Manuscript Collection-Columbia. 
Most of these dedication ceremonies took place before World War I and praised male heroism. It was only after the Great War that Western Daughters gave more room to the accomplishments of pioneer women. This new focus was actually the consequence of a failure, namely the Daughters' failure to build a national highway that followed the routes of the old pioneer trails: the National Old Trails Road. Although the Daughters did quite a bit of lobbying before World War I, US Congress was unwilling to fund the project. It was only after this defeat that the national DAR opted for an alternative, namely 12 identical ten-foot statues, which were to be erected in 12 trail states to honor the pioneer mother. These statues were finally erected in 1928 and 1929, respectively.22 The statue was called the "Madonna of the Trail," and it was inspired by the watercolor of a pioneer woman, which had first appeared in the widely read general interest magazine "Century Magazine” in 1909.

The DAR's Madonna of the Trail campaign reflected the same gendered ambiguities that characterized the Daughters' tributes to Revolutionary women. The likeness of the resolute pioneer woman was actually armed, holding a rifle in her right hand, and appeared ready to defend her loved ones against potential attacks. ${ }^{23}$ But as in the case of the Revolution, this rather unfeminine militancy was seen as an exception that only reflected the pioneer woman's natural instincts as a wife and mother. A speech by Arlene Moss, the chairwoman of the National Old Trails Committee, during a dedication ceremony that took place in Bethesda, Maryland, in 1929, shows how the Daughters' interpretations of the Madonna's significance echoed earlier appraisals. In that speech, Moss said: "We are at last paying tribute to the silent and patient 'Madonnas of the Trail'-brave in their sacrifice, loyal to their men, following them trustfully carrying the coming race in their arms." ${ }^{24}$ As in the case of the Revolution, the Daughters applauded pioneer women's selfless service to others as well as their loyalty toward the nation and

22 E. B. Gentry, Report of Good Roads Committee, D.A.R., November 1911, Van Brunt Papers, Folder 13; E. B. Gentry, National Old Trails Road Department, in: DAR Magazine, August-September 1914, pp. 132-135; H.R. 2864, 63d Congress, $1^{\text {st }}$ Session, House of Representatives, April 14, 1913; Plan to Preserve and Mark Famous Old Trails, in: New York Times, August 26, 1917, p. 54; H.R 8011, 65th Congress $2^{\text {nd }}$ session, House of Representatives, January 3, 1918; DAR, National Old Trails Committee, Resolution, 1924, folder "Resolutions - National Old Trails Road Committee, 1924," box 1 (series 1), Madonna of the Trail Collection, DAR Archives, Washington, DC; Invitation, DAR, Missouri State Society Scrapbooks, v. 8, 1928, Western Historical Manuscript Collection-Columbia; Bethesda Old Trails Shaft to Mark Route, in: Washington Post, July 22, 1928, p. 24.

23 "'Madonna of the Trail Statuette," folder "Reference File, Madonna of the Trail, DAR Magazine, 1914-1993,” HG Papers, series 2.6 Administrative, DAR Archives, Washington, DC; "Amelia M. McFig, 'Pioneer Mothers' Memorial Monument," June 22, 1929, folder "Dedication and Unveiling of the New Mexico Madonna, 1928-1929," box 3, series 2, Madonna of the Trail Collection, DAR Archive, Washington, DC.

24 Quoted in "Old Trails Road Marker Unveiled," April 1929, newspaper clipping, Scrap Book "Daughters of the American Revolution in Georgia, 1929-1932," Georgia State Archives, Morrow, GA. 
their men, but they refrained from any argument that would call for more gender equality as a reward for their heroism.

The final example of the Daughters' use of the gendered memory of heroism in their efforts to strengthen American patriotism concentrates on the memory of Native Americans and reveals much about the role of race in the DAR's nationalist interpretations of the past. In the DAR's tales of Western expansion, Native Americans presented a predicament: they were depicted as the racial "other" that white settlers had to subdue to build the nation; yet, they also had to be integrated into the DAR's vision of a united nation in the present. In the Daughters' interpretations of the past, the solution to this predicament was the memory of friendship. All across the nation, DAR chapters focused on friendship and cooperation between white settlers and Native Americans in their commemorative activities. Conflict was not entirely absent from their stories, but in the case of monuments, the vast majority of them either commemorated loyal chiefs who had supported the US Army in various military conflicts or reminded people of the many treaties in which tribes had agreed to cede their land to the United States. ${ }^{25}$

In this cheerful reading of US history, women once more played a pivotal role because the Daughters suggested that Native American women had a seemingly inborn interest in interracial friendship and in assisting white male nationbuilders. ${ }^{26}$ In their efforts to commemorate Indian women's patriotic assistance, one woman received particularly lavish praise. That woman was Sacajawea. In the early nineteenth century, this member of the Shoshone tribe had been part of the famous Lewis and Clark expedition, which had explored the vast territory of the Louisiana Purchase, a vast swath of land that France sold to the United States in 1803. In the DAR's commemoration of this expedition, Sacajawea became the

25 B. M. Haines, Historic Work Along the St. Joseph, in: American Monthly Magazine, May 1912, pp. 262-264; To Place Granite Boulder in Commemoration of Treaty, in: Atlanta Constitution, July 30, 1911, p. B12; Treaty of Peace to be Observed in Coleraine Monument to be Unveiled in Commemoration, in: Macon Daily Telegraph, June 17, 1912, p. 6; History of the Saginaw Chapter Daughters of the American Revolution, 1924, pp. 15-17, DAR Michigan Papers, box 22, University of Michigan, Bentley Library, Ann Arbor; Captain Christopher Robinson Chapter, in: DAR Magazine, February 1918, pp. 103-104; M. Lindly, Nebraska State History DAR, pp. 355-357; A. C. Benning, For Aged Couple an Appeal is Made, in: Atlanta Constitution, January 31, 1909, p. D8; Memorials of the Days Before 1776, Erected by the Daughters of the American Revolution, in: American Monthly Magazine, January 1906, pp. 3-4 (1-10); Americus D.A.R. to Unveil Chehaw Monument Friday, in: Atlanta Constitution, June 10, 1912, p. 3; L. Y. Franklin, Historic Spots in Mississippi, in: American Monthly Magazine, November 1911, pp. 261-262; Daughters of the American Revolution: Treaty Oak, in: The State (Columbia, SC), November 1, 1911, p. 15; Monument to Creek Indians Is Finished, in: Macon Daily Telegraph (Macon, GA), January 1, 1912, p. 2; Captain Richard Somers Chapter, in: DAR Magazine, March 1915, pp. 147-148.

Mrs. J. S. Owen, Pocahontas, Mother of an Empire, in: American Monthly Magazine, November 1907, p. 702; L. C. Baughman, Colonial Women, in: American Monthly Magazine, October 1909, p. 987. 
epitome of the loyal Native American woman who happily assisted white explorers to conquer the continent and to subdue its indigenous population. Of course, the Daughters were not the only ones to remember Sacajawea. Citizens of Portland, Oregon, had erected a bronze statue of the brave Indian woman as early as 1905 , and similar statues were erected in other parts of the country in the following two decades. ${ }^{27}$ Yet, the Daughters probably made the most explicit connection between Native American loyalty and American nationalism, which is suggested by a bronze tablet that was dedicated in 1914 by the Montana DAR. Its inscription reads in part: "In patriotic memory of Sacajawea, [...] whose heroic courage, steadfast devotion and splendid loyalty in acting as guide across the Rocky Mountains made it possible for the Lewis and Clark Expedition [...] to occupy so important a place in the history of this Republic." 28 In the eyes of the Daughters, then, even indigenous women could be heroines, but their heroic status hinged on their willingness to assist white men in the process of American nationbuilding, a process that was inextricably intertwined with white supremacy. In the hands of the Daughters, heroism could become both a means of patriotism and a form of paternalistic oppression, which integrated Native Americans into their vision of a united nation but almost completely ignored centuries of dispossession and genocide.

However, by comparison, African Americans fared even worse than America's indigenous population, since the Daughters almost completely ignored the history of black citizens. Not until the 1980s did the organization acknowledge that almost 5,000 soldiers of color had fought for American independence. Patriotic black women were similarly absent from their historical narratives for much of the twentieth century. If people of African descent appeared in these stories at all, they were portrayed as faithful slaves who happily supported their benevolent masters, not as heroic figures who helped win American independence. ${ }^{29}$ Racism could thus elevate those who killed the racial "other" to heroic stature, while erasing the cultural memory of non-white heroes and heroines, whose influence as "hero makers" was not powerful enough to affect dominant white narratives of American heroism. Since the Daughters barred black women from

27 D. J. Kessler, The Making of Sacagawea: A Euro-American Legend, Tuscaloosa, AL 1996; L. Blee, Completing Lewis and Clark's Westward March: Exhibiting a History of Empire at the 1905 Portland World's Fair, in: Oregon Historical Quarterly 16, Issue 2, 2005, pp. 232 253; In Sacajawea's Honor, in: Anaconda Standard (Anaconda, MT), October 1, 1914, p. 28; Honor Indian Heroine, in: Washington Post, November 9, 1914, p. 5.

B. Taft Keith, Montana Daughters Unveil a Tablet, in: DAR Magazine, December 1914, p. 306.

29 W. L. Scruggs, Slavery in Colonial Days, in: American Monthly Magazine, November 1894, pp. 429-435; M. S. Pechin, The Bond Slaves; Or, the White Indentured, in: American Monthly Magazine, October 1900, pp. 323-332; Mrs. H. H. McCluer, Social Life of George Washington, September 15, 1932, DAR Missouri Collection, Scrapbook vol. 17, 1932-33, Western Historical Manuscript Collection, UMKC, University Archives, Kansas City, MO. 
membership until the 1970s, African Americans were unable to challenge the DAR's remembrance of the past, but they did so with a vengeance in the 1980s, when a black woman from Washington, DC forced the organization's leadership to finance research on black members of the Continental Army and to encourage women of color to join the Daughters, threatening them with legal action if they refused. ${ }^{30}$

\section{Conclusion}

The answer to the question that was posed at the beginning of this essay, namely the question of how the DAR used the gendered memory of heroism to strengthen American patriotism, speaks volumes to the ambiguities of heroism in the United States in general and the contributions of the Daughters of the American Revolution to its memory in particular. The Daughters used memory to construct and strengthen both national loyalty and nationalized gender identities. Heroism served as the conceptual linkage between these two categories. The Daughters invoked the heroic exploits of Revolutionary patriots, Western pioneers, and Native Americans to foster national loyalty. At the same time, their tales of male and female heroism strengthened traditional gender hierarchies and suggested that the stability of the nation depended on these hierarchies. Even Native Americans could be heroic, but they were also expected to accept the gendered as well as the racial hierarchies that the Daughters deemed essential to the nation's future.

In terms of a general assessment of the Daughters' nationalist endeavors, it is difficult to come to an unequivocal conclusion. The organization was able to wield enormous cultural power during an era that offered women few avenues for advancement. More importantly, the Daughters not only demonstrated that women had made patriotic contributions in the past but proved women's patriotic agency in the present. Yet, they uncritically accepted nineteenth-century gender ideals, continually warning that any challenge to these ideals would jeopardize the nation. Ultimately, regardless of whether we call the Daughters feminist conservatives or conservative feminists, their history testifies to the vital role that white elite women played in American nationalism prior to World War II. The Daughters were thus more than a passive audience that happily consumed the heroic fare that was served to them by government officials, the print media, or

30 DAR Welcomes Its First Black, in: Chicago Tribune, December 4, 1977, p. 3; J. Trescot, National DAR Admits Black, in: Washington Post, May 10, 1983, p. B3; R. Kessler, Black Unable to Join Local DAR, in: Washington Post, March 12, 1984, p. A1; M. A. Slacum, D.C. City Council's Clark Threatens DAR's Tax Break, in: Washington Post, March 13, 1984, p. B2; Woman Accuses DAR of Racism, in: New York Amsterdam News, March 17, 1984, p. 4; Woman Banned from DAR Gets Help to Form Chapter, in: Jet, April 9, 1984, p. 9; L. Santus Ferguson, A Memorial to Forgotten Black Patriots, in: Wall Street Journal, March 21, 1986, p. 28. 
other patriotic organization. Rather, they actively shaped the heroic stories they not only deemed to be true but also regarded as a crucial element in their endeavor to strengthen the national loyalty of America's citizenry and thus exerted influence on the memory of heroism beyond the confines of its membership roster more generally.

However, our historical inquiry should not stop there. The example of the DAR invites us to ponder additional questions that could be addressed by scholars of heroism. For example, if the Daughters were one particular audience that not only read existing American hero narratives but also tried to actively shape them, examining how they vied and competed with other groups that were involved in hero-making processes would certainly prove fruitful. Comparing the DAR with the United Daughters of the Confederacy (UDC), for instance, yields important new insights, since the latter's focus-the memory of the American Civil War from a southern perspective-did present challenges to the Daughters' vision of national unity. The frequent overlap of membership between the DAR and the United Daughters of the Confederacy was fraught with a potential for sectional tensions. Founded in 1894, the UDC was a women's organization that proved enormously popular among white middle-class Protestants in the South, including members of the DAR. By the end of World War I, the UDC claimed to have 100,000 members. During the preceding two decades, it had spearheaded a tremendously influential movement that coped with the South's military defeat by idealizing antebellum society and the notions of white racial superiority it was based on as well as by praising the heroic valor of the Confederate soldiers who had defended it. Through such means as monuments, textbooks, and historical preservation, its members sought to controvert what they regarded as northern historical falsehoods, primary among them the idea that southern secession was an act of rebellion and that Confederate soldiers had been disloyal to the United States. Although DAR members who belonged to the UDC repeatedly contended that they were loyal citizens of the United States, the rival organization's goals clearly appeared to counter the vision of national unity and loyalty that the DAR stressed in their commemorative campaigns. ${ }^{31}$ It was therefore not surprising that sectional tensions occasionally erupted into verbal vitriol. In 1912, for instance, president general Mrs. Matthew Scott's decision to decorate Continental

31 Organized New Chapter, in: Washington Post, May 20, 1905, p. 4; Funeral of Miss Desha, in: Washington Post, January 31, 1911, p. 2; K. L. Cox, Dixie's Daughters: The United Daughters of the Confederacy and the Preservation of Confederate Culture, Gainesville, FL 2003, pp. 1-9, pp. 94-96; K. McMichael Stott, From Lost Cause to Female Empowerment: The Texas Division of the United Daughters of the Confederacy, 1896-1966, Ph.D. diss., University of North Texas, 2001, pp. 5-6, pp. 162-163; D.A.R. Delegates Are Welcomed to Capital, in: Washington Post, April 17, 1906, p. 3; All the Woman's Clubs News of Georgia, in: Atlanta Constitution, July 16, 1905, p. D6; Echoes of Flag Day, in: Atlanta Constitution, June 30, 1912, p. C7; Flag Day Observed, in: Washington Post, June 13, 1913, p. 3; Power of the South, in: Washington Post, November 13, 1912, p. 1. 
Hall with the Confederate flag next to the Stars and Stripes for the opening of a UDC convention in the building elicited strong protest from a number of northern Daughters, including the organization's co-founder Mary Lockwood. 32

Although such tensions flared up only occasionally, they became a concern to DAR leaders, who came up with two major strategies to calm sectional passions. The first strategy, which was introduced only in 1914, was simply to ban any discussions on the subject. ${ }^{33}$ The second strategy had been utilized since the DAR's founding and was probably the more successful one because it stressed commonalities rather than differences. It revolved around the common heroism of southern and northern soldiers, especially during the wars in which the two sections stood shoulder to shoulder to defend the United States. Southern members in particular evoked the valor of the members of the Continental Army during the American Revolution as proof of shared "revolutionary blood," while the exploits of US soldiers during the Spanish-American War were regarded by members from all regions as an unquestionable sign of national unity and sectional reconciliation. The DAR's careful handling of this sensitive topic thus reflected and contributed to the general discourse of sectional reconciliation, which stressed the heroism of white soldiers and the common racial interests of Southerners and Northerners. ${ }^{34}$ These efforts to curb sectional tempers as well as the fact that the DAR and the UDC shared similar gender ideologies-which stressed women's patriotic contributions to US history but refrained from directly challenging existing gender discrimination-contributed to fairly cordial relations between the two organizations. ${ }^{35}$ Although the United Daughters of the Confederacy seemed to challenge the DAR's efforts to strengthen patriotism and national unity, then, the shared idea that the United States was a white nation that had been built and defended through the efforts of white heroic warriors contributed to strong bonds of white sisterhood.

32 Row in D.A.R. Congress, in: Chicago Daily Tribune, February 23, 1900, p. 8; Flags Cause Controversy, in: Washington Post, November 24, 1912, p. E1.

33 Stirs D.A.R. Anger, in: Washington Post, April 21, 1914, p. 12.

34 N. Silber, The Romance of Reunion: Northerners and the South, 1865-1900, Chapel Hill, NC 1993, p. 164; The Daughters in Congress, in: Atlanta Constitution, October 19, 1895, p. 2, pp. 11-12, pp. 168-169; Daughters of Revolution Celebrate Anniversary, in: Atlanta Constitution, July 5, 1902, p. 8; Substitutes for 'Dixie,' in: Atlanta Constitution, July 16, 1905, p. D6; S. D. Parker, Greeting to Ga. Daughters from the New State Regent, in: Atlanta Constitution, May 10, 1914, p. B6; E. C. Pittman, Woman and Society, in: Atlanta Constitution, March 2, 1899, p. 9; K. Mason Rowland, War Between the States, in: Washington Post, April 30, 1899, p. 17; Wendt, Krieg und Heldentum in den USA (footnote 7).

35 Like the DAR, the UDC disputed male-centered accounts of the past and men's efforts to confine them to the sphere of the home but did not demand woman suffrage or other political rights. Rather, just as the DAR, the UDC regarded motherhood and women's seemingly sex-specific sentiments as the driving force behind their efforts to enlarge their cultural and political influence in American society. See Cox, Dixie's Daughters (footnote 31); McMichael Stott, From Lost Cause to Female Empowerment (footnote 31), pp. 5-6, pp. 162-163. 
As indicated by the examples that have been discussed in this essay, the history of the Daughters of the American Revolution can teach us much about heroes and their audiences. For one thing, the DAR must be considered an "active" audience because it also became an important hero maker. At the same time, the conservative women's organization was one "interpretive community" among many and had to react to and reconcile various other interpretive communities, both among the organization's member and vis-à-vis other non-governmental groups as well as state and federal politicians and agencies. As a hereditary patriotic organization, moreover, the DAR is a peculiar case of "self-heroization," since the heroism of its members' ancestors was seen as both a privilege and a form of social distinction in the present. Many Daughters vicariously shared in the heroism of their grand-grandfathers and grand-grandmothers, feeling themselves confirmed in their belief in the racial superiority of white Anglo-Saxon protestants. The fact that the Daughters were related by blood to the heroes and heroines they honored resulted in an emotional investment in their work that was much greater than it would have been in the case of exceptional historical figures that were "merely" fellow countrymen and countrywomen. Clearly, the history of heroism in the United States cannot be fully comprehended without examining the Daughters of the American Revolution and like-minded organizations. 